\title{
Corporate Governance and Tata Steel Governance
}

\author{
Dr. Mita Mehta ${ }^{* 1}$, Dr. Arti Chandani ${ }^{2}$ \\ ${ }^{1}$ Associate Professor, Symbiosis International (Deemed University), Symbiosis Institute of Management \\ ${ }^{2}$ Associate Professor, Symbiosis International (Deemed University), Symbiosis Institute of Management
}

\begin{abstract}
Corporate governance denotes the rules, functions and practices which help the organizations to work. The purpose of this report is to review the papers related to corporate governance in various companies, which mainly refers to the employee engagement. The effective corporate governance provides transparency and good business environment to the responsible organizations. On the other hand, the effective corporate governance practices can increase the value of the organization in the competitive environments. The problem is in designing effective corporate governance which provides effective performance to the company and the agency problem. The announcement of a sound corporate governance certainly will not guarantee transparency and the accountability of responsibilities. Irrespective of the gender, the board members have high level of responsibilities and they must be accountable for their role. The human resource is very crucial in an organization. The policy makers must work a lot on the economic outcomes during the options to consider a particular policy. The findings of the research on the corporate governance suggested to implement efficient control procedures internally in the organization which have a cooperative attitude and limitations from the laws created which will help in protecting the investors effectively.
\end{abstract}

Keywords - Corporate Governance; Transparency; Responsibilities; Practices

\section{Introduction}

Corporate governance, on a broad level, has two aspects to be considered: control over the company and performance of the company and managing these aspects is one of the goals of any corporate governance policy. Corporate governance creation and its guidelines can be traced back to the 1980s. During the early days, companies faced several difficulties in managing the organizations and businesses effectively which culminated in formation of the discipline of corporate governance. With time, the banks, governments, multilateral institutions and organizations started to understand and identify the problems present in their operations and in order to improve customer engagement, these organizations started to formulate policies which formed the basis of the topic. The main goal of these policies were to safeguard the organizations from bankruptcy, enforcing proper structure of ownership, base lining stock market practices and making the board of directors more accountable for their decisions.

\section{Review of Literature}

\subsection{Independent Directors}

As per the study of (MEHTA \& COOMAR, 2016), the role played by the independent directors is observed to be the most difficult job as the various bodies of the management like the stakeholders often demand more transparency in all the operations performed in the organization.
The study of (Giovannini, 2010), relates that it is very important for the organizations must work on their practices of the corporate governance principles to achieve transparency as demanded by the committee members of the organization.

It is stated in (MEHTA \& COOMAR, 2016), that the role played by the independent director is elevated as the controllers who are provided with the freedom to challenge or question anything in an appropriate manner. The study determines that a good independent director contains the qualities of constructive in opposing anything happening wrong. Moreover, independent director should also possess the visualization of broad picture in their mind. They must adopt a role which neutralizes the interests of all the stakeholders. They must be more empowering in fulfilling their responsibilities effectively. Finally, it is also mentioned that only the independent directors must not be assumed to be the responsible person for the deficiencies present in the board. The independent directors are requested to add on values in the completed performance level of the organization. According to ("Corporate Governance: An International Review", 2009), it is revealed that irrespective of the gender the board members have high level of responsibilities and they must be accountable for their role.

\subsection{Human Resource}

As per the study of (Mehta, Tewari, \& Chandani, 2017), it is determined that the human resource is very crucial in an organization. The employees are considered as an asset which is intangible. Their satisfaction and work 
performance makes the organization gain sustainability in the competitive environment. If their satisfaction is not met then it impacts on their work which in turn affects the performance of the organization. This study has observed that the engagement level of the employee determines the performance of the employees. The performance of their work correlates with the market value of the organization with the rival companies. As per (Bahman, Kamran, \& Mostafa, 2014), the research of this paper determines that the organizations must not only focus on the shareholders but it is required to bring in a balance between the employees, communities, society and shareholders.

\subsection{Shareholders and Management}

According to (Khan, 2011), the main cause for a good relationship between the management and the shareholders is referred to corporate governance code, which the board develops and implements in controlling the operations of the organization. Further, the study focuses on the accountability of each individual to decrease the principalagent problem faced in an organization. If the agency problem is not reduced it will help the managers in gaining more private benefits which can damage the performance of the organization. This is the reason that this study also enforces on the importance of sound corporate governance in the organization to be in the competition for a long run. The well- structured corporate governance codes help in discarding the conflicts related to ownership and control. The agency problem is resolved by two basic types of contracts one is to instruct managers to perform in the interest of investors and legal rights to control the investors.

There is an argument in (Bahman, Kamran, \& Mostafa, 2014), that the shareholders select the management who work as the agents to them and the only responsibility of the management is to act on the principles that best interests the shareholders.

\subsection{Economic Outcomes and Policy Makers}

According to ("G20/OECD Principles of Corporate Governance Updated", 2015), legal rule's implementation in an organization can have impact on the economic outcomes. Thus, it is noted that the policy makers have a major role to play here to create a flexible framework that will meet all the corporate operations in various conditions. On the other hand, the other factors that come under flexibility are the structure, sectors of activity, geographical presence, development stage of the organization, ownership and control of the organization. It is also suggested to the policy makers, that they must work a lot on the economic outcomes during the options to consider a particular policy. The main thing which they should analyze is to check the effects that is imposed on the market functioning. To stop the impacts it is very essential to have sound and transparent markets to discipline the market participants and in helping them to be accountable.

Even according to the study of (Pan, 2013), wellstructured legal regulations by the corporate governance code is essential in having internal control to protect from the investors. In order to meet an effective code, more number of policies must be developed by the policy makers which can ultimately provide confidence of investors to the organization.

As per (Cuomo, Mallin, \& Zattoni, 2015), the corporate governance codes must be updated by the policy makers and they must continue to develop these codes. The legislators must address the potential failures in the operations of the corporate governance.

\subsection{Responsibilities}

It is stated in ("G20/OECD Principles of Corporate Governance Updated", 2015), that the corporate governance demands to provide clarity so to see a clear outcome it is very much important to divide the responsibilities among the authorities present in the organization which can guarantee the accountability of the authorities to serve the public interest. Thus, based on the law the public authority must be protected effectively.

According to (Witherell, 2002), the responsibilities of the managers doesn't end with honest financial reporting, but it also requires to perform the fundamental functions of conducting business operations and in obeying the laws which are appropriate. The key responsibility mentioned in this paper is to maintain relationship among the business and societies. This can be achieved by meeting the demands of the society according to the shareholders. Even according to (Bahman, Kamran, \& Mostafa, 2014), the organizations not only expect to be responsible to the shareholders of the company but it must also be responsible even to the society. The companies which are considered as a responsible company have met the standards of sustainable ideologies and methods.

\subsection{Creative Accounting Practices}

According to (Mudel, 2017), the corporate governance is considered that the organizations are directed and controlled which connected with the accounting practices which are creative, then with the ownership structure and the structure of the board of director. It is said in this paper that all these connected factors can either be encouraged or discouraged by the accounting practices which are creative. The practices of creative accounting can have a major effect based to the issues of corporate governance and thus 
it is considered as a weakness of the corporate governance. As per (A. Bebchuk \& S. Weisbach, 2009), the earnings management implementation is focused more during 1997 to 2002. The option- and stock- based compensation packages are interlinked with the manipulation of aggressive accounting. According to (K. Rao \& A. Tilt, n.d.) nowadays, it is essential to have control on the changes in terms of global economy with respect to the increasing social activism, international trade, newly adventing expectations, globalization and demanding transparency to manage the business effectively around the globe.

As per (Goodwin, 2015), the shareholder activism is involved in the hedge funds and in monitoring the differences based on the efforts of the earlier activists by other institutional investors. When compared to the pension funds and mutual funds the hedge funds have more influence to the corporate boards and managements. This is because; the main differences mainly start with the incentive structures and the form of the organization. This paper mainly focuses on the two questions stating, "What are the causes for the involvement of the hedge fund activist and the characteristics of the Target Firms?" and "Is there any enduring value for the hedge fund activism for the target firms and their shareholders?

It is stated in (A. Bebchuk \& S. Weisbach, 2009), that a specific question is given more weightage is given to the impact of the activism on profitability. Relating to this question, the following question arises that whether the activists produce any kind of value to the organization and to the shareholders or they are affecting the shareholders. These questions are standard question of this research paper. The solution to such questions is a debate which focuses on the optimal scope of the shareholder's rights in public companies. Thus, the conclusion to this debate in this research is provided that activism either gives strength to the rights of the shareholders rights, or its limits the support.

\subsection{Corporate Governance and Board and Data}

Corporate Governance and Board of Directors - The new Company's act was passed in 2013 and to streamline CG regulations, even SEBI made certain revisions to streamline the norms and rules [revised Clause 49, 2014], but it turned out that the revisions by SEBI were overarching stricter and sterner than Company's act in most cases. Companies must make a judgement and decide which regulations are sterner and follow those.

Comparison between corporate governance norms stated in companies act 2013 and Revised Clause 49 of SEBI - Area of comparison Revised Cl 49 Co's Act 2013.
Composition of Board - especially regarding independent directors not less than $50 \%$ should be executive directors and there should be one woman-director.

- Non- Executive Chairman-1/3rd of the board should be Independent directors [ID].

- Executive Chairman- half of the board should be Independent directors.

- At least $1 / 3$ rd of the board should be Independent directors.

Appointment of a new Independent Director On appointing, profile and letter of appointment of the ID should be sent to the stock exchange and put on the cowebsite within 1 day Required (no specifications mentioned) Director compensation Stock option cannot be offered to ID but can be given to non-executive directors.

No stock options are to be offered to IDs Liability of ID or non-executive - No specifications provided in acts of omissions or commissions to be judged from board processes whether they were occurred with his knowledge with his consent. Only in those cases the ID or NonExecutive Director will be considered liable.

Separation of offices of CEO and Chairman - Only a non- mandatory provision introduced. Separation was required. Exceptions:

- Articles of the company permit otherwise

- Company does not have multiple businesses.

Frequency of directorships - An Individual can be serving as ID for 7 listed companies. If he/she is a WTD, can only serve 3 directorships can serve as ID for 20 companies but max 10 listed companies. Provisions regarding Board of Directors according to Clause 49 [Revised] are:

- Max Tenure of Independent Directors: An ID can serve upto 5 years with a company, the tenure can be increased by 5 more years by passing a resolution by the company. If a person wants to serve for more than the above 10 years as an ID, he/she can do so after 3 years of ceasing to be an ID in that company.

- Performance Evaluation of ID and BOD: Evaluation method has recently been moved from voluntary board evaluation to a mandatory board evaluation. The provisions are as under:

- Role of the Nomination and Remuneration Committee (NRC): It will formulate the criteria for evaluation and will also be responsible for carrying out the evaluation of every director's performance. Additionally, the committee will also determine the continuance or cessation of the appointment of the directors based on their performance evaluation ratings.

- Role of ID: IDs will meet without the presence of the non-independent directors and the management. They 
will review the performance or non-ID and the board as a whole as well as the Chairperson of the company. This is necessary as ID bring an objective opinion regarding the performance of the board and the company's management.

- Evaluation of IDs: done by the entire board excluding the respective director being evaluated.

- Disclosure Provisions: a general declaration in a statement mentioning the process of evaluation will be included in the BOD's report. Performance evaluation methods used for IDs will be disclosed in the CG report.

\section{Tata Steel: Introduction}

The Chairperson is Mr. Natarajan Chandrasekaran and the CEO is Mr. T. V. Narendran. The Chairman and CEO are different. Tata Group has always been celebrated to be compliant to the international corporate governance standards. Had there been the same person on both the positions which are the most influential positions in the company, it is against the investor's interest because the chairman's position is created in order to safeguard the investors and the chairman is supposed to oppose any decisions taken by the CEO that might have an adverse impact on investor's income i.e. reduction in dividend, and will result to abuse of power.

- The corporate governance part in the integrated annual report of Tata Steel has the following clarifications on certain allegations made against it:

- Regulators sought for sharing of information during leadership transition of Tata Sons.

- Investment in corus group plc were made wherein the board clarifies stating that the decision was made after careful considerations and has brought a good fortune for Tata Steel. It was inherently an act of Growth Strategy.

- Mandatory committees according to the act are:

- Audit Committee

- Nomination and Remuneration Committee

- Stakeholder Relationship committee

- CSR committee

However, at Tata Steel, we see various other committees over and above the mandatory ones. The Board committees are:

- Audit Committee

- Nomination and Remuneration Committee

- Stakeholder Relationship committee

- CSR committee

- Risk Management

- Safety Health and Environment

- Ethics and Compliance Committee

- Executive committee of the board
Extra- ordinary General Meeting: on 21st December 2016 the company convened and EGM on requisition of Tata Steel's Principal Shareholder Tata Sons Ltd. The proposals for removal of Mr. Cyrus P. Mistry and Mr. Nusli N. Wadia as Directors of the Company were made.

Promoter Holding: Promoters hold $31.35 \%$ in Tata Steel. They are the principal and largest shareholder in the company.

\section{Board of Directors:}

- There are 10 Directors on the board of Tata Steel. 2 are EDs 3 NEDs and 5 IDs including a Woman Director. Hence, we see $50 \%$ of the board is comprised with Ids, which is compliant with the criteria set by SEBI [NED as chairman therefore 1/3rd of the board must be of ID].

- The Company has issued formal letters of appointment to the IDs. As required by Regulation 46 of the SEBI Regulations, 2015.

- Details about the Board Members: Mr. Koushik Chatterjee is the Group Executive Director and CFO and represents Corporate \& Europe sections of the company. Mr. Parvatheesam $\mathrm{K}$ is the Company Secretary. Mr Mr. T. V. Narendran being the MD and CEO majorly handles India and South East Asian business.

- The Chairman Emeritus is Mr Ratan Tata. And he is the promoter director as of now.

- Board meetings were held 11 times in the year. The intervening gap between the meetings was according the Act and listing regulations.

- Directorships of each board member across the world: Name of Director category Indian public companies companies worldwide board committees

- Mr. Aman Mehta was appointed as Additional Director (Independent) with effect from March 29, 2017

Table 1. Board Committees details

\begin{tabular}{|c|c|c|c|c|c|}
\hline $\begin{array}{c}\text { Name of } \\
\text { Director }\end{array}$ & $\begin{array}{c}\text { Cate } \\
\text { gory }\end{array}$ & $\begin{array}{c}\text { Indian } \\
\text { Public } \\
\text { Compa } \\
\text { nies }\end{array}$ & $\begin{array}{c}\text { Comp } \\
\text { anies } \\
\text { world } \\
\text { wide }\end{array}$ & \multicolumn{2}{|c|}{$\begin{array}{c}\text { Board } \\
\text { Committees }\end{array}$} \\
\hline $\begin{array}{c}\text { Mr. N. } \\
\text { Chandrasekara } \\
\text { n }\end{array}$ & NED & 6 & 7 & - & - \\
\hline $\begin{array}{c}\text { Mr. Ishaat } \\
\text { Hussain }\end{array}$ & NED & 10 & 15 & 2 & 5 \\
\hline $\begin{array}{c}\text { Mr. D. k. } \\
\text { Mehrotra }\end{array}$ & NED & 7 & 8 & 3 & 3 \\
\hline $\begin{array}{c}\text { Ms. Mallika } \\
\text { Srinivasan }\end{array}$ & ID & 7 & 9 & - & \\
\hline Mr. O. P. Bhatt & ID & 3 & 5 & 2 & 3 \\
\hline
\end{tabular}




\begin{tabular}{|c|c|c|c|c|c|}
\hline $\begin{array}{c}\text { Mr. Andrew } \\
\text { Robb }\end{array}$ & ID & 1 & 4 & - & 1 \\
\hline $\begin{array}{c}\text { Dr. Peter } \\
\text { (Petrus) } \\
\text { Blauwhof }\end{array}$ & ID & 1 & 7 & & \\
\hline $\begin{array}{c}\text { Mr. Aman } \\
\text { Mehta* }\end{array}$ & ID & 6 & 9 & 2 & 5 \\
\hline $\begin{array}{c}\text { Mr. Koushik } \\
\text { Chatterjee }\end{array}$ & ED & 4 & 8 & - & 1 \\
\hline $\begin{array}{c}\text { Mr. T. V. } \\
\text { Narendran }\end{array}$ & ED & 2 & 5 & - & \\
\hline
\end{tabular}

Table 2. Attendance of each board member with their positions/category

\begin{tabular}{|l|l|r|l|}
\hline Name of Director & Category & Attendance & $\%$ \\
\hline Mr. N. Chandrasekaran & NED & 2 & 100 \\
\hline Mr. Ishaat Hussain & NED & 11 & 100 \\
\hline Mr. D. k. Mehrotra & NED & 9 & 82 \\
\hline Ms. Mallika Srinivasan & ID & 9 & 82 \\
\hline Mr. O. P. Bhatt & ID & 11 & 100 \\
\hline Mr. Andrew Robb & ID & 11 & 100 \\
\hline Dr. Peter (Petrus) Blauwhof & ID & 1 & 100 \\
\hline Mr. Koushik Chatterjee & ED & 11 & 100 \\
\hline Mr. T. V. Narendran & ED & 11 & 100 \\
\hline
\end{tabular}

\section{Performance Evaluation of the Board}

The Board evaluated the effectiveness of its functioning, that of the Committees and of individual Directors. The Board, through NRC, sought the feedback of Directors on various parameters such as: Degree of fulfilment of key tasks towards stakeholders (by way of monitoring corporate governance practices, participation in the long-term strategic planning, etc.).

- Role clarity and composition of Board and Committees;

- Level of coordination between the Board and its Committees;

- Value of the discussions and process management; Board/Committee culture and dynamics; and

- Quality of relationship between Board Members and the Management.

The Chairman of the Board had meetings with nonexecutive board members. These meetings were intended to obtain Directors' inputs on effectiveness of the Board/Committee processes. The board measured and discussed the efforts received from the Directors. Also, the IDs at their meeting reviewed the performance of the Board, Chairman of the Board and that of Non-Executive Directors.

\section{Compensation Policy}

Board has approved remuneration policy based on the recommendation of NRC committee which is meant for Directors, Key Managerial Personnel ('KMP') and all other employees of the Company. As part of the policy, the Company strives to ensure that:

- The level and composition of remuneration is reasonable to attract, retain and motivate Directors for the quality required to run the company.

- Association between remuneration and performance is clear and meets necessary performance benchmarks.

- Remuneration to Directors, KMP and Senior Management involves a balance between fixed and incentive pay, reflecting short, medium, and long-term performance objectives appropriate to the working of the Company and its goals.

\section{Cessation of Tenure of Directors}

According to the SEBI guidelines, Tata Steel also follows the Maximum Tenure of 10 years for Independent Directors. They also have the policy of IDs retiring once they achieve the age of 75 years Whistle Blower Policy. The Company's Vigil Mechanism provides a formal mechanism for all Directors, employees and business associates to approach the Ethics Counselor / Chairman of the Audit Committee and make protective disclosures of the unethical behaviour, actual, violation or suspected fraud of the TCoC.

\section{Conclusion}

The research work of various researchers concludes that the corporate governance provides transparency to the organization. Research also bolsters the fact that effective corporate governance practices can increase the value of the organization in the competitive environments. It is determined from the research that a responsible independent director must be constructive in opposing anything which is incorrect and he/she should visualize the broad picture and must adopt a role to neutralize the stakeholder's interests. Directors must be more empowering in fulfilling their responsibilities effectively. Finally, it is also established that only the independent directors must not be assumed to be responsible for the deficiencies present in the board. It is revealed that irrespective of the gender, the board members have high level of responsibilities and they must be accountable for their role. The review of various papers suggests that the policy maker must evaluate carefully the economic outcomes before opting for a particular policy. The most important aspect which should be analyzed is the effects that can be imposed on the market functioning. It is evident

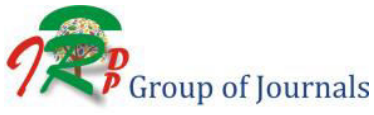


from research that a mere announcement of a sound corporate governance policy does not guarantee transparency and an active engagement from all the employees is necessary in order for a particular policy to be implemented successfully.

\section{References}

[1] Bebchuk, L. \& S. Weisbach, M. (2009). The state of corporate governance research. National bureau of economic research.

[2] Bahman, S., Kamran, N., \& Mostafa, E. (2014). Corporate social responsibility: A literature review. African Journal Of Business Management, 8(7), 228-234. http://dx.doi.org/10.5897/ajbm12.106

[3] Corporate Governance: An International Review. (2009). Women Directors On Corporate Boards: A Review And Research Agenda, 17(3).

[4] Cuomo, F., Mallin, C., \& Zattoni, A. (2015). Corporate Governance Codes: A Review and Research Agenda. Corporate Governance: An International Review, 24(3), 222-241. http://dx.doi.org/ 10.1111/corg. 12148

[5] Giovannini, R. (2010). Family ownership, Coporate Governance and Performance of Italian Firms. Guglielmo Marconi Uiversity, Rome, Italy.
[6] Goodwin, S. (2015). Corporate Governance and Hedge Fund Activism. SSRN Electronic Journal. http://dx.doi.org/ 10.2139/ssrn.2646293G20/OECD Principles of Corporate Governance Updated. (2015). Board Leadership, 2015(142), 4-4. http://dx.doi.org/10.1002/bl.30032

[7] Khan, H. (2011). A Literature Review of Corporate Governance. International Conference On E-Business, Management And Economics, 25.

[8] K. Rao, K. \& A. Tilt, C. Corporate Governance And Corporate Social Responsibility: A Critical Review, Flinders Business School.

[9] Mehta, M. \& Coomar, S. (2016). Literature Review Of Corporate Governance And The Role Of Independent Directors. IJRCM, 7(5).

[10] Mehta, M., Tewari, P., \& Chandani, A. (2017). Employee Engagement - Review. A Multidisciplinary Journal Of Global Macro Trends.

[11] Mudel, S. (2017). Creative Accounting and Corporate Governance: A Literature Review. SSRN Electronic Journal. http://dx.doi.org/10.2139/ssrn.2708464

[12] Pan, L. (2013). A Contemporary Literature Review of Corporate Governance: An Overview. SSRN Electronic Journal. http://dx.doi.org/10.2139/ssrn.2256968

[13] Witherell, B. (2002). Corporate governance and responsibility Foundations of market integrity. Corporate Governance- OECD Principles.

[14] www.tatasteel.com (website accessed on $22^{\text {nd }}$ July 2018) 